\title{
Nursing Therapy in Hallucinations of Schizophrenia Patients A Literature Review
}

\author{
Angga Sugiarto ${ }^{1)}$; Suyanta ${ }^{1)}$; Erna Erawati ${ }^{1)}$; Sri Handayani2) \\ akhanggas@gmail.com
}

\begin{abstract}
Background: Hallucination is a problem that appears in schizophrenia as a positive symptom that must be addressed immediately so as not to disturb the health status. Nursing therapy is the main alternative to resolve hallucinatory problems in schizophrenic patients who are treated at the Mental Hospital.

Methods: The method used is literature review with a library of articles or journals from 2010-2019 by searching through Google Scholar, Pro Quest, GALE, EBSCOhost, and Ovid Journal.

Results: The results of the synthesis show that nursing therapy can overcome the problem of hallucinations in schizophrenic patients.

Conclusion: CBT and group activity therapy as nursing therapy are effective for hallucinations of schizophrenia

Keyword : Nursing Therapy; Hallucinations; Schizophrenia;

1) Nursing Study Program of Magelang, Health Polytechnic of Semarang, Indonesia

Jl. Perintis Kemerdekaan, Magelang, Indonesia

2) RSJ Prof. dr. Soerojo Magelang,

Jl. Ahmad Yani, Magelang, Indonesia
\end{abstract}

Background. Schizophrenia is one of the severe and chronic mental disorders that affects more than 21 million people worldwide (WHO, 2019). The prevalence of severe mental illness in Indonesia is 1,7 per mile (Balitbangkes, 2013). The highest prevalence of households with the highest incidence of schizophrenia / psychosis mental disorders were Bali (11 per mile), DIY and NTB (10 per mile) Aceh, Central Java, South Sulawesi, and West Sumatra (9 per mile) (Badan penelitian dan Pengembangan Kesehatan Kementerian Kesehatan RI, 2018).

In schizophrenia there are positive and negative symptoms, where one of the positive symptoms is hallucinations (Videbeck, 2010) (Hawari, 2014). Schizophrenia treatment was done in two ways namely pharmacological and non pharmacological (Stuart and Laraira, 2005). Pharmacological therapy can be in the form of antipsychotics known as neuroleptic (Nugroho, 2012). Non-pharmacological therapy in schizophrenia includes nursing therapy.

Methods. The method used is literature review with library sources using journal articles from 2010 - 2019 through Google Scholar, Pro Quest, GALE, EBSCOhost, and Ovid Journal. The author synthesizes the articles obtained with the search keywords nursing therapy, hallucinations, and schizophrenia.

Result and Discussion. Nursing therapy using group therapy in hallucinations of schizophrenic patients shows an increase in the ability to control hallucinations. Session 1-2 perception stimulation group activity therapy on the ability to control hearing halusination in the skizofrenia patients shows an increase in the ability to control hallucinations (Halawa, 2015). The results of the study on 55 respondents using I-III Group Activity Therapy found 65.5\% had an increased ability to control hallucinations (Muhammad Qodir, Anjas Surtiningrum and Nurullita, 2013). Quasy experimental research of Group Activity Therapy on 20 respondents showed that there was a significant influence on the influence TAK sensory-perception stimulation of the ability to control hallucinations on hallucinations patients indicated by $p=0,000$ (Hidayah, 2015).

The other nursing therapy was modified nursing therapy. One frequent done now in patients with schizophrenia is cognitive therapy, behavioral therapy, cognitive behavioral therapy. The results of applying cognitive behavioral therapy enhance the client's ability 
to use rational responses against negative thoughts and behaviors, thereby reducing cognitive, affective and negative behavioral responses, and increasing the ability of families to care for clients with hallucinations. The results of applying behavioral therapy on 20 hallucinations patient enhance the client's ability to fight negative thoughts that arise when hallucinations arise. The results of applying cognitive therapy also enhance the client's ability to perform positive behaviors when hallucinations appear (Nyumirah, 2014).

The Effect Of Cognitive Behaviour Therapy On Clients With Halusination Nursing Problems is cognitive, affective, client behavior significantly improved, and hallucinations decreased by $47 \%$. CBT also increases the cognitive, affective and psychomotor abilities of hallucinatory patients with the highest results up to 57\% (Hastuti and Setianingsih, 2016). (Wahyuni, 2010) in his research on 28 schizophrenic clients who had hallucinations found that cognitive behavior therapy (CBT) can reduce hallucinogenic symptoms by $34.5 \%$, while the ability to control hallucinations increases by $18 \%$.

CBT using individually tailored caseformulation that aimed to reduce hallucinations statistically significant effect-sizes was 0.44 with hallucinations, effect-size for CBT for hallucinations increased (0.49) (M, LR and F, 2014). An acceptance-based cognitive behavioural therapy for command hallucinations in psychotic disorder at 43 participants with problematic command hallucinations were randomized to receive 15 sessions of the intervention "TORCH" (Treatment of Resistant Command Hallucinations) or the control, Befriending, then followed up for 6 months. A sub-sample of 17 participants was randomized to a waitlist control before being allocated to TORCH or Befriending. Participants engaged equally well with both treatments. Despite $\mathrm{TORCH}$ participants subjectively reporting greater improvement in command hallucinations compared to Befriending participants (F et al., 2012).
Generalist nursing actions comply with nursing care standards, namely identifying hallucinations that appear (content, type, duration, situation and response), controlling hallucinations by rebuking or expelling, conversing with others, carrying out activities and taking medication regularly, and performing therapeutic activity of perception stimulation. This is in accordance with research conducted by Caroline et al (Nyumirah, 2014) that the application of hallucinatory client nursing care standards in controlling hallucinations will affect the cognitive and psychomotor abilities of the client, so that hallucinatory clients will experience a decrease in sign intensity andhallucinatory symptoms that appear.

Generalist therapy is an intervention nursing that is commonly done in asylums through direct application implementation strategy according to the problem patient nursing. Generalist therapy consists from individual therapy and group therapy. Suitable therapy to practice socialization the patient is group therapy. There is patient interaction with patients and patients with nurses in a therapy group. Group therapy assesses sensitivity social and collaboration that occur within interactions between patients and patients with nurse (Kurniasari, Dwidiyanti and Sari, 2019)

The other therapy is cognitive therapy, personality therapy (behavioral therapy), Cognitive Behavioral and others (McQuaid cit (Kurniasari, Dwidiyanti and Sari, 2019)). Nursing actions that can be performed for both individual and family clients with hallucinations include individual therapy is cognitive behavioral therapy (CBT) that the application of psychosocial therapy with cognitive behavior can change negative thought patterns into positive ones, so that maladaptive behaviors become adaptive.

Cognitive therapy (CT) according to Copel is a therapy that helps clients to develop rational thought patterns and according of Fauziyah Cognitive behavioral therapy can improve cognitive abilities and behavior of schizophrenic clients with violent behavior 
(Nyumirah, 2014), and improve cognitive abilities and behavior hallucinatory client (Wahyuni, 2010).

Rieckert states that CBT therapy can significantly reduce anger, guilt and low selfesteem. The application of CBT in hallucinations of clients was trained to recognize various events that occurred in his life, including unpleasant events. Clients are also taught to recognize feelings that arise from the way clients interpret the events they experienced and the actions taken after experiencing these feelings (Hastuti and Setianingsih, 2016). Cognitive behavioral therapy can be given to schizophrenic clients, which makes clients able to control angry behavior, control clients who talk to themselves or hallucinations and can improve client relationships in the hospital, family and at work (MD, 2009).

Conclusion and Suggestions. The results of the synthesis show that nursing therapy can overcome the problem of hallucinations in schizophrenic patients. CBT and group activity therapy as nursing therapy are effective for hallucinations of schizophrenia. CBT and group activity therapy are recommended for hallucinations of schizophrenia.

Acknowledgements. Thanks to the researchers say to all those who have helped in completing this research.

\section{References}

Badan penelitian dan Pengembangan Kesehatan Kementerian Kesehatan RI (2018) Laporan Nasional Riskesdas 2018. Jakarta.

F, S. et al. (2012) 'A Randomised Controlled Trial of Acceptance-Based Cognitive Behavioural Therapy for Command Hallucinations in Psychotic Disorders', Pub.Med, 50(2), pp. 110-21. Available at: https://www.ncbi.nlm.nih.gov/pubmed/221 86135.

Halawa, A. (2015) 'PENGARUH TERAPI AKTIVITAS KELOMPOK: STIMULASI PERSEPSI SESI 1-2 TERHADAP KEMAMPUAN MENGONTROL HALUSINASI PENDENGARAN PADA PASIENSKIZOFRENIA DI RUANG FLAMBOYAN RUMAH SAKIT JIWA $\begin{array}{lrr}\text { MENUR } & \text { SURABAYA', } & \text { Jurnal } \\ \text { Keperawatan, } & 4(1) . & \text { doi: }\end{array}$ 10.2320/materia.46.171.

Hastuti, R. Y. and Setianingsih (2016) 'Pengaruh Cognitive Behaviour Threapy pada Klien dengan Masalah Keperawatan Perilaku Kekerasan dan Halusinasi di RSJD DR. RM Soedjarwadi Klaten', Jurnal Keperawatan Jiwa, 4(1), pp. 7-12. Available at: https://jurnal.unimus.ac.id/index.php/JKJ/ article/view/3907/3638.

Hawari, D. (2014) Skizofrenia Pendekatan Holistik (BPSS) Bio-Psiko Sosial-Spiritual. Jakarta: Badan Penerbit Fakultas Kedokteran Universitas Indonesia.

Hidayah, A. N. (2015) 'Pengaruh Terapi Aktivitas kelompok Stimulasi persepsiSensori terhadap Kemampuan Mengontrol Halusinasi di RSJD Dr. Amino Gondohutomo Semarang', Jurnal keperawatan, 8(1), pp. 44-55. doi: $10.1145 / 3132847.3132886$.

Kurniasari, C. I., Dwidiyanti, M. and Sari, P. (2019) 'Terapi Keperawatan Dalam Mengatasi Masalah Interaksi Sosial pada Pasien Skizofrenia: Literatur Review', Jurnal IImu Keperawatan Jiwa, 2(1), pp. 41-46. Available at: https://scholar.google.co.id/scholar?hl=id \&as_sdt $=0 \% 2 \mathrm{C} 5 \& \mathrm{q}=\mathrm{TERAPI}+\mathrm{KEPERAW}$ ATAN+DALAM+MENGATASI+MASALAH +INTERAKSI+SOSIAL+PADA+PASIEN+ SKIZOFRENIA\&btnG=\#d=gs_qabs\& $u=\%$ 23p\%3DbZZ38-xS7bwJ.

M, V. D. G., LR, V. and F, S. (2014) 'The effects of Individually Tailored Formulation- Based Cognitive Behavioural Therapy in Auditory Hallucinations and Delusions: A metaanalysis.', Pub.Med, 156(1), pp. 30-7. Available

at: https://www.ncbi.nlm.nih.gov/pubmed/247 31619.

MD, A. K. M. (2009) 'Cognitive Behavior Therapy for People with Schizophrenia', Psyciatry, 6(12), pp. 32-39. Available at: https://www.ncbi.nlm.nih.gov/pmc/articles/ PMC2811142/. 
Muhammad Qodir, A., Anjas Surtiningrum, N. and Nurullita, U. (2013) 'PENGARUH TERAPI AKTIVITAS KELOMPOK ORIENTASI REALITAS SESI I-III TERHADAP KEMAMPUAN MENGONTROL HALUSINASI PADA KLIEN HALUSINASI DI RSJD Dr. AMINO GONDOHUTOMO SEMARANG', ejournal.stikestelogorejo.ac.id. Available at:

http://ejournal.stikestelogorejo.ac.id/index. php/ilmukeperawatan/article/view/158/182.

Nugroho, A. E. (2012) Farmakologi : Obat-Obat Penting dalam Pembelajaran IImu Farmasi dan Dunia Kesehatan. Yogyakarta: Pustaka Pelajar.

Nyumirah, S. (2014) 'Manajemen Asuhan keperawatan Spesialis Jiwa pada Klien Halusinasi di Ruang sadewa di RS DR. H Marzoeki Mahdi Bogor', Jurnal Keperawatan Jiwa, 2(1), pp. 1-13. Available at: https://jurnal.unimus.ac.id/index.php/JKJ/ article/view/3906/3637.
Stuart, G. W. and Laraira, M. T. (2005) Principles and Practice of Psychiatric Nursing. 8th Editio. Missouri: Mosby, Inc.

Videbeck, S. L. (2010) Psychiatric-Mental Health Nursing. Sixth Edit. Philadelphia: Lippincott Williams \& Wilkins.

Wahyuni, S. E. (2010) Pengaruh Cognitive Behaviour Therapy terhadap Halusinasi Pasien di Rumah Sakit Jiwa Pemprovsu Medan. Universitas Indonesia. Available at: http://lib.ui.ac.id/detail.jsp?id=137113.

WHO (2019) Schizophrenia, Home/Newsroom/Fact sheets/ Detail. Available at: https://www.who.int/newsroom/fact-sheets/detail/schizophrenia. 